\title{
PENGARUH STORE ATTRIBUTE TERHADAP LOYALITAS WISATAWAN DIKONTROL OLEH MOTIVASI BERBELANJA
}

\author{
Bunga Astari, Lili Adi Wibowo, Oce Ridwanudin \\ Universitas Pendidikan Indonesia \\ oceridwanudin@gmail.com
}

\begin{abstract}
Bandung is one of the cities which has many potentials in shopping tourism. Year after years the number of the shopping center in Bandung is increasing. Although shopping tourism in Bandung become the main destination for shopper but the customer loyalty is in a low state of condition. The customer more interest to try something new. So many new products that the competitors offered has caused the customers difficult to be loyal. By Creating the store attribute strategy is expected could increase the customer loyalty and could be more understand the shopper motives. This study is a descriptive and verificative and used explanatory survey method and cross sectional approach. The number of sample in this study were 111 respondents, those are the tourists who shopped in Bandung. The sampling technique that is used was simple random sampling. The Data analysis technique used is multiple regression. The independent variable in this research is the store attribute $(X)$ which has three dimensions, those are store atmosphere (X1), convenience (X2), merchandise (X3), promotion $(X 4)$, interpersonal communication (X5), while the dependent variable is the loyalty (Y). Tourist's responses to store attribute and loyalty considered sufficiently high, the majority of tourist has a hedonic shopping motives. Based on the result of this study, it shows that store attribute is influencing the tourist's loyalty controlled by shopping motives.
\end{abstract}

Keywords-Store Attribute; Shopping Motives; Loyalty; Shopping Tourism

\section{PENDAhUluan}

Wisata belanja merupakan salah satu sektor industri pariwisata yang mengalami pertumbuhan yang signifikan di dunia. Berbelanja sudah menjadi suatu hal yang dilakukan oleh wisatawan setiap mereka berwisata baik wisatawan nusantara maupun mancanegara, tidak lengkap rasanya apabila wisatawan dalam suatu perjalanan tidak menghabiskan waktu untuk berbelanja. Selain berbelanja untuk banyak orang sudah menjadi salah satu cara meluangkan waktu. Dalam dalam perjalanan satu hari, liburan panjang atau perjalanan bisnis, berbelanja sudah menjadi isu penting untuk sekarang ini (LeHew dan Wesley, 2007; Friedrich dan Sattler,2005)

Indonesia merupakan Negara yang memiliki potensi untuk menjadi destinasi wisata belanja dunia. Salah satu kota besar yang turut mendorong perkembangan sektor wisata belanja di Indonesia adalah Kota Bandung. Bandung yang dikenal dengan julukkan "Paris Van Java" yang memiliki arti Kota Paris dari Pulau Jawa, karena Bandung dikenal dengan keindahan dan kesejukannya serta sebagai kiblat dalam dunia fashion. Akan tetapi, meskipun wisata belanja di Kota Bandung tidak pernah sepi setiap minggunya tingkat loyalitas wisatawan belanja masih sangat rendah. Berdasarkan hasil penelitian-penelitian terdahulu menunjukkan loyalitas wisatawan belanja di Kota Bandung mengalami penurunan yang mana pada tahun 2013 jumlah wisatawan yang loyal sekitar 5,18\% dan pada tahun 2014 menjadi 4,22\% hal itu terjadi karena persaingan industri wisata belanja semakin ketat dimana pusat perbelanjaan di Kota Bandung setiap tahunnya terus bertambah dan tersebar dimanamana sehingga wisatawan sulit untuk dapat setia pada suatu destinasi wisata belanja selain itu rendahnya loyalitas wisatawan belanja dikarenakan adanya motivasi wisatawan. (Novianti, 2014; Haryanto, 2014).

Berdasarkan penelitian Yanuar (2013:6), terdapat beberapa beberapa faktor yang mempengaruhi loyalitas wisatawan belanja diantaranya motivasi wisatawan serta daya tarik suatu tempat belanja. Ketika berbelanja terdapat faktor motivasi yang merupakan kecenderungan dalam diri seseorang yang membangkitkan topangan, tindakan serta upayanya untuk mencapai kepuasan baik secara rasioanl maupun emosional. Setiap wisatawan memiliki perilaku yang berbeda serta kebutuhan dan keiinginan 
yang berbeda maka dari itu pengelola suatu tempat wisata belanja harus mampu memahami wisatawan.

Selain itu, Store Attribute merupakan salah satu hal penting yang perlu diperhatikan untuk meciptakan loyalitas dalam wisata belanja karena store attribute dapat merangsang wisatawan dalam pembentukan motivasi berbelanja serta dapat menciptakan loyalitas wisatawan, hal tersebut ditegaskan dengan pernyataan Nguyen et.al dalam Subagio (2011:9) yaitu "Semakin baik store attribute maka akan memberikan stimulus kepada pembelanja dalam motif berbelanja dan menciptakan loyalitas".

Melihat permasalahan tingkat loyalitas wisatawan belanja di Kota Bandung yang rendah diharapkan dengan meningkatkan nilai store attribute di destinasi wisata belanja Kota Bandung dapat menciptakan loyalitas serta memahami motivasi berbelanja setiap wisatawan. Secara umum penelitian dilakukan untuk mengetahui pengaruh Store Attibute terhadap loyalitas wisatawan yang dikontrol oleh motivasi berbelanja. Dalam penelitian ini akan difokuskan kepada Factory Outlet dan Trade Center yang tersebar di Kota Bandung.

\section{KAJIAN PUSTAKA}

\section{A. Store Attribute dalam Manajemen Pemasaran}

Kotler dan Keller (2014:5) mendefinisikan "Marketing management as the art and science of choosing target markets and getting, keeping, and growing customers through creating, delivering, and communicating superior customer value". Store attribute merupakan salah satu strategi pemasaran yang dapat memberikan stimuli ketika konsumen berbelanja dengan melalui pemahaman motif berbelanja sehingga dapat tercipta rasa puas dan loyalitas terhadap suatu destinasi wisata belanja.

Wang dan Ha (2011:327) menjelaskan definisi store atribute bahwa "Store attribute is consumer's perceptions of store offerings and image". Store attribute di bentuk oleh pengelola store yang menjadi pembeda dengan store lain serta merupakan stimuli dari ekternal yang dapat menimbulkan persepsi wisatawan terhadap store tersebut. Konsumen akan memiliki persepsi yang berbeda pada setiap store, hal tersebut bergantung pada bagaimana pengelola store membentuk citra kepada konsumen. Store attribute dapat menjadi perangsang sehingga dapat menarik perhatian wisatawan serta wisatawan dapat memutuskan tempat belanja mana yang akan dikunjungi.
Store attribute terdiri dari beberapa dimensi yang diantaranya: Kesatu, Store atmosphere yang merupakan suasana lingkungan di dalam toko terdiri dari ciri-ciri fisik toko seperti tata letak, tampilan visual, warna, penerangan, dan suara yang menciptakan citra toko dalam pikiran konsumen. Kedua, convenience meliputi kenyamanan aksesibilitas ke pusat perbelanjaan atau toko. Ketiga, merchandise merupakan karakteristik produk yang tersedia di toko atau pusat perbelanjaan seperti kualitas, variasi produk, dan gaya produk. Keempat, promotions yaitu kegiatan tempat belanja dalam memberikan informasi kepada pelanggan mengenai penawaran produk dan menginformasikan seperti apa citra toko kepada pelanggan, dan yang terakhir adalah interpersonal communication yaitu interaksi karyawan dengan pelanggan dengan cara yang ramah.

\section{B. Motivasi Berbelanja}

Menurut Robbins dalam Sangadji dan Sopiah (2013:154) motivasi adalah kesediaan untuk mengeluarkan tingkat upaya yang tinggi untuk tujuan organisasi yang dikondisikan oleh kemampuan upaya itu untuk memenuhi beberapa kebutuhan individual, sedangkan berbelanja merupakan suatu kegiatan membeli suatu produk untuk memenuhi keinginan. Motivasi berbelanja terbagi menjadi dua yaitu motif belanja utilitarian dan belanja hedonik. Arnold dan Reynolds dalam Nguyen et.al (2006:230) bahwa motif belanja hedonik adalah perilaku yang mengacu pada kecenderungan untuk rekreasi, kesenangan, intrinsic, dan orientasi pada rangsangan suatu motivasi, karena berbelanja merupakan suatu hal yang menarik dan dapat menghilangkan rasa jenuh, stress. Selain itu konsumen yang memiliki sifat hedonik ini seringkali tidak peduli berapa banyak uang yang dikeluarkan untuk berbelanja demi mendapatkan kepuasan dan kebahagiaan.

Babin et.al dalam Nguyen et.al (2006:230) menjelaskan motif utilitarian merupakan motif seseorang yang beroriantesi pada kualitas dari suatu produk dan rasional ketika berbelanja memikirkan dari suatu manfaat dan kebutuhannya. Konsumen yang memiliki motif belanja utilitarian lebih memikirkan manfaat dari suatu produk serta lebih berorientasi kepada kebutuhan. Tipe konsumen ini akan lebih konsisten kepada tujuan utamanya tidak terpengaruh terhadap jenis barang lain atau seperti adanya potongan harga atau tidak.

\section{Loyalitas}

Zeithaml, Bitner, dan Dwayne (2009:47) menjelaskan loyalitas merupakan sebuah komitmen mendalam untuk membeli kembali atau menjadi pelanggan tetap dari sebuah 
produk atau jasa yang disukai secara konsisten di masa yang akan datang, dimana komitmen tersebut menyebabkan pembelian yang berulang terhadap produk yang sama, meskipun pengaruh-pengaruh situasional dan usaha-usaha pemasaran mempunyai kesanggupan atau kemungkinan untuk mengakibatkan perubahan perlilaku. Loyalitas terdiri dari tiga dimensi diantaranya: 1). Say positive things, berupa penyampaian kepada orang lain dalam bentuk kata-kata secara positif tentang suatu penyedia produk atau jasa, biasaya berupa ulasan cerita atau uraian pengalaman, 2). Recommend friends, proses yang berujung pada mengajak pihak lain untuk ikut menikmati produk atau jasa tersebut akibat dari pengalaman positif yang dirasakan, 3). Continue purchasing, sikap untuk membeli ulang terus menerus oleh konsumen tersebut pada penyedia produk atau jasa tertentu sehingga menimbulkan perulangan yang dapat dilandasi dari kesetiaan.

\section{Metode PENELITIAN}

Penelitian ini menganalisis tentang pengaruh store attribute terhadap loyalitas wisatawan belanja yang dikontrol oleh motivasi berbelanja. Store Attibute merupakan variabel bebas (independent variable) yang terdiri dari lima dimensi diantaranya: store atmosphere, convenience, merchandise, promotion, interpersonal communication. Selain itu motivasi berbelanja menjadi kontrol pada penelitian ini yang terbagi menjadi dua yaitu motif belanja hedonic dan motif belanja utilitarian. Sedangkan loyalitas merupakan variabel terikat (dependent variable) terdiri dari tiga dimensi yaitu say positive things, recommend friends, continue purchasing. Unit analisis dalam penelitian ini adalah wisatawan yang berbelanja di Kawasan Factory Outlet dan Trade Center di Kota Bandung.

Pada penelitian ini metode yang digunakan adalah metode penelitian deskriptif dan verifikatif sesuai dengan variabel-variabel yang diteliti.

Ukuran sampel dihitung dengan menggunakan rumus Tabanichnick dan Fidel (2013:123) dan sampel yang diambil untuk penelitian ini sebnayak 111 wisatawan yang pernah berbelanja di Kawasasn Factory Outlet dan Trade Center Kota Bandung dengan proporsi $60 \%$ kuesioner dibagikan di Kawasan Trade Center dan sebesar $40 \%$ di kawasan Factory Outlet. Teknik pengumpulan data yang digunakan diantaranya dengan studi literature, observasi dan penyebaran angket.

Berdasarkan hipotesis konseptual yang diajukan, terdapat hubungan antara variabel bebas terhadap variabel terikat dan dikendalikan oleh variabel kontrol. Hipotesis tersebut digambarkan dalam sebuah paradigma seperti terlihat pada Gambar 1 berikut

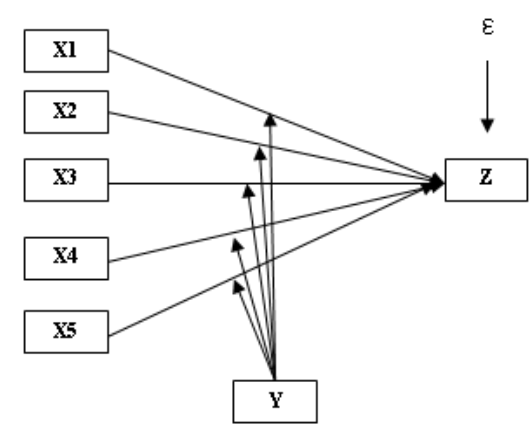

GAMBAR 1. PARADIGMA PENELITIAN

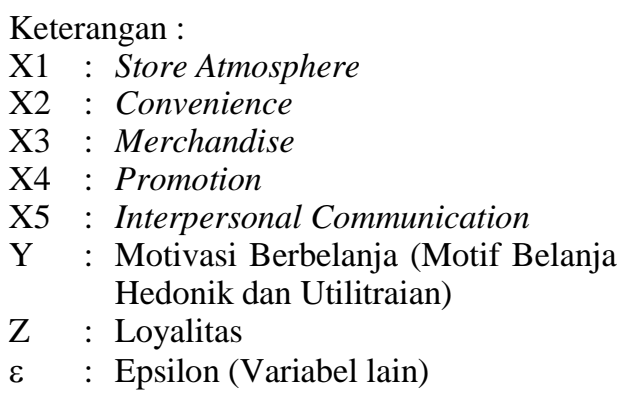

Kriteria pengambilan keputusan hipotesis secara statistik dalam rangka pengambilan keputusan penerimaan atau penolakan hipotesis dapat ditulis sebagai berikut:

1. $\mathrm{H}_{0}: \mathrm{F}_{\text {hitung }}<\mathrm{F}_{\text {tabel }}$ artinya tidak terdapat pengaruh yang signifikan antara store attribute yang terdiri dari store atmosphere, convenience, merchandise, promotion, interpersonal communcitaion terhadap loyalitas wisatawan belanja dikontrol oleh motivasi berbelanja

2. $\mathrm{H}_{1}: \mathrm{F}_{\text {hitung }}>\mathrm{F}_{\text {tabel }}$ artinya terdapat pengaruh yang signifikan antara store attribute yang terdiri dari store attribute yang terdiri dari store atmosphere, convenience, merchandise, promotion, interpersonal communcitaion terhadap loyalitas wisatawan belanja dikontrol oleh motivasi berbelanja

\section{HASIL PENELITIAN DAN PEMBAhasan}

A. Tanggapan Wisatawan Terhadap Store Attribute Kawasan Wisata Belanja Factory Outlet dan Trade Center di Kota Bandung 
TABEL 1. REKAPITULASI TANGGAPAN WISATAWAN BELANJA TERHADAP STORE ATTRIBUTE

\begin{tabular}{llll}
\hline No. & Dimensi & $\begin{array}{l}\text { Total } \\
\text { Skor }\end{array}$ & $\begin{array}{l}\text { Rata-Rata } \\
\text { Skor }(\%)\end{array}$ \\
\hline 1 & Store Atmosphere & 1.352 & 23 \\
\hline 2 & Convenience & 797 & 13 \\
\hline 3 & Merchandise & 1.255 & 21 \\
\hline 4 & Promotion & 716 & 12 \\
\hline 5 & $\begin{array}{l}\text { Interpersonal } \\
\text { Communication }\end{array}$ & 1.822 & 31 \\
\hline Total & & 5.942 & 100 \\
\hline
\end{tabular}

Tabel 1 menunjukkan rekapitulasi skor dari setiap dimensi store atttibute, dimensi yang memperoleh rata-rata skor tertinggi adalah dimensi InterpersonalCommunication yaitu dengan jumlah skor 455,5. Tingginya tanggapan terhadap dimensi interpersonal communication membuktikan bahwa pelayanan yang diberikan oleh karyawan sudah baik. Karyawan di wisata belanja Kota Bandung mendapatkan tanggapan yang positif dari wisatawan bahwa mereka dapat melayani dengan ramah, sopan dan santun sehingga wisatawan merasa senang dengan perlakuan karyawan. Mendapatkan pelayanan yang baik yang membuat wisatawan belanja di Kota Bandung merasa dihargai sebagai pembeli dan tidak segan untuk meminta suatu pertolongan kepada karyawan.

Sedangkan dimensi promotion memperoleh rata-rata skor terendah yaitu sebesar 358 . Promosi di wisata belanja Kota Bandung masih jarang dilakukan sehingga dimensi promosi mendapatkan tanggapan terendah dari wisatawan padahal wisatawan belanja Kota Bandung sangat senang jika ada penawaran diskon. Hal tersebut terbukti dengan adanya event atau bazar konsumen lebih tertarik berbelanja pada kegiatan tersebut salah satunya seperti acara Trademark yang merupakan kegiatan rutin setiap tahun dimana pada acara tersebut produk-produk yang dijual mendapat potongan harga.

B. Hasil Tanggapan Wisatawan Terhadap Motivasi Berbelanja

TABel 2. Motivasi Berbelanja Wisatawan DI KaWASAN FACTORY OULET DAN TRADE CENTER Kota BANDUNG

\begin{tabular}{llll}
\hline Kawasan & $\begin{array}{l}\text { Motif } \\
\text { Hedonik } \\
\text { (satuan } \\
\text { orang) }\end{array}$ & $\begin{array}{l}\text { Motif } \\
\text { Utilitarian } \\
\text { (satuan } \\
\text { orang) }\end{array}$ & Total \\
\hline $\begin{array}{l}\text { Factory } \\
\text { Outlet }\end{array}$ & 37 & 8 & 45 \\
\hline $\begin{array}{l}\text { Trade } \\
\text { Center }\end{array}$ & 39 & 27 & 66 \\
\hline TOTAL & 76 & 35 & 111 \\
\hline$\%$ & 68,5 & 31,5 & 100 \\
\hline
\end{tabular}

Berdasarkan Tabel 2 dapat dilihat bahwa sebagian besar wisatawan memiliki motif hedonik yang dimana pada awalnya mereka tidak berniat untuk berbelanja akan tetapi ada faktor-faktor yang membuat ia melakukan pembelian. Setiadi (2003:96) mengungkapkan hedonic shopping motives merupakan suatu kebutuhan yang bersifat psikologis seperti rasa puas, gengsi, emosi, dan perasaan subjektif lainnya. Kebutuhan ini seringkali muncul untuk memenuhi tuntutan sosial dan estetika dan disebut juga motif emosional. Seseorang biasanya tidak berpikir panjang untuk melakukan pembelian suatu barang karena motif hedonik secara emosional lebih sulit dikontrol.

C. Hasil Tanggapan Wisatawan Terhadap
Loyalitas

TABEL 3. REKAPITULASI TANGGAPAN WISATAWAN DI WISATA BELANJA KOTA BANDUNG TERHADAP LOYALITAS

\begin{tabular}{llll}
\hline No. & Dimensi & Total Skor & $\begin{array}{l}\text { Rata-Rata } \\
\text { Skor }(\%)\end{array}$ \\
\hline 1. & $\begin{array}{l}\text { Say Positive } \\
\text { Things }\end{array}$ & 769 & 34,5 \\
\hline 2. & $\begin{array}{l}\text { Recommend } \\
\text { Friends }\end{array}$ & 721 & 32,3 \\
\hline 3. & $\begin{array}{l}\text { Continue } \\
\text { Purchasing }\end{array}$ & 742 & 33,2 \\
\hline TOTAL & 2.232 & 100 \\
\hline
\end{tabular}

Rekapitulasi tanggapan wisatawan belanja di kawasan Factory Outlet dan Trade Center Kota Bandung terhadap loyalitas, dimensi say positive things mendapat skor tertinggi yaitu sebesar 769 artinya, wisatawan belanja di Kota Bandung sudah cukup loyal dengan dibuktikannya kesediaan wisatawan belanja untuk menceritakan hal positif mengenai produk atau jasa yang ditawarkan di wisata belanja Kota Bandung mendapat penilaian yang tinggi. Lovelock et.al (2012:206) menjelaskan bahwa informasi yang di dapat dari pelanggan lain umumnya dipandang lebih kredibel daripada kegiatan promosi yang diprakarsai perusahaan dan dapat memiliki pengaruh keputusan orangorang berkuasa untuk menggunakan (atau menghindari menggunakan) layanan. Selain itu, dimensi recommend friends mendapatkan total skor terendah yaitu sebesar 721 .

D. Pengaruh Store Attribute Terhadap Loyalitas Wisatawan Belanja yang Dikontrol oleh Motivasi Berbelanja

Persamaan regresi berganda dummy untuk pengaruh store attribute terhadap loyalitas wisatawan yang dikontrol oleh motivasi berbelanja dapat dinyatakan sebagai berikut:

$$
\begin{gathered}
\mathrm{Y}=\beta_{\mathrm{o}}-\beta_{1} \mathrm{X}_{1}+\beta_{2} \mathrm{X}_{2}+\beta_{3} \mathrm{X}_{3}+\beta_{4} \mathrm{X}_{4}+\beta_{5} \mathrm{X}_{5}+ \\
\beta_{6} \mathrm{D}_{1}+\varepsilon \\
\mathrm{Y}=0,322 \mathrm{X}_{1}+0,647 \mathrm{X}_{2}+0,416 \mathrm{X}_{3}+ \\
1,030 \mathrm{X}_{4}+(-, 043) \mathrm{X}_{5}+(-1,089) \mathrm{D} 1
\end{gathered}
$$


Berikut merupakan perhitungan slope motif belanja hedonik dan utilitarian:

Model Regresi Variabel Dummy untuk Kode 1 = Motif Belanja Utilitarian :

$$
\begin{gathered}
\mathrm{Y}=0,322 \mathrm{X}_{1}+0,647 \mathrm{X}_{2}+0,416 \mathrm{X}_{3}+ \\
1,030 \mathrm{X}_{4}+(-0,043) \mathrm{X}_{5}+(-1,089) * 1 \\
\mathrm{Y}=1,283
\end{gathered}
$$

Model Regresi Variabel Dummy untuk Kode $0=$ Motif Belanja Hedonik :

$$
\begin{gathered}
\mathrm{Y}=0,322 \mathrm{X}_{1}+0,647 \mathrm{X}_{2}+0,416 \mathrm{X}_{3}+ \\
1,030 \mathrm{X}_{4}+(-0,043) \mathrm{X}_{5}+(-1,089) * 0 \\
\mathrm{Y}=2,372
\end{gathered}
$$

Maka, dapat dilihat bahwa nilai slope Motif Belanja Hedonik > dari slope Motif Belanja Utilitarian, dengan nilai slope 2,372 > 1,283 dapat disimpulkan bahwa wisatawan yang berbelanja di Kota Bandung lebih banyak yang memiliki motif belanja hedonik dibandingkan dengan motif utilitarian.

Uji F digunakan untuk mengetahui seberapa besar pengaruh keseluruhan variabel bebas terhadap variabel terikat. Uji $\mathrm{F}$ dapat dilakukan dengan membandingkan Fhitung dengan Ftabel untuk menguji signifikansi dari analisis regresi. Dari hasil uji $\mathrm{F}$ atau uji keseluruhan maka didapat nilai $\mathrm{F}$ adalah sebesar 25.943 dengan tingkat signifikansi 0,000 atau < dari 0,050. Dengan demikian, model dari tabel tersebut dapat dikatakan Fit dan menghasilkan penolakan terhadap $\mathrm{H}_{0}$. Hal tersebut juga dapat diartikan bahwa secara simultan store attribute memiliki pengaruh yang signifikan terhadap loyalitas wisatawan belanja di Kota Bandung yang dikontrol oleh motivasi berbelanja.

\section{KESIMPULAN}

Berdasarkan hasil penelitian yang telah dilakukan dengan menyebarkan 111 kuesioner kepada wisatawan belanja di Kota Bandung yang bertujuan untuk mengetahui pengaruh store attribute terhadap loyalitas wisatawan belanja yang dikontrol oleh motivasi berbelanja, maka dapat disimpulkan bahwa; 1) secara umum tanggapan store attribute wisata belanja di Kota Bandung yang teridir dari store atmosphere, convenience, merchandise, promotion, dan interpersonal communication mendapat penilaian yang tinggi. Dimensi promotion mendapat tanggapan paling rendah, hal itu dikarenakan daya tarik promosi yang dilakukan di wisata belanja Kota Bandung masih rendah dan jarang dilakukan. Dimensi interpersonal communication mendapat tanggapan paling tinggi yang dimana karyawan wisatawa belanja di Kota Bandung mampu berkomunikasi dengan baik dengan para wisatawan belanja. Komunikasi yang baik, perlakuan ramah serta sopan terhadap pelanggan sangat penting untuk diperhatikan karena perlakuan karyawan dalam melayani wisatawan dapat merubah mood ketika berada di tempat belanja. 2) Tanggapan wisatawan belanja terhadap loyalitas yang teridiri dari say positive things, recommend friends, dan continue purchasing dinilai cukup tinggi. Indikator say positive things mendapatkan tanggapan tertinggi dari wisatawan, hal ini menunjukkan bahwa kesediaan wisatawan untuk menceritakan hal positif mengenai produk atau jasa yang ditawarkan di wisata belanja baik Kawasan Factory Outlet maupun Trade Center sudah tinggi. Salah satu ciri wisatawan yang loyal adalah wisatawan yang mau memberikan informasi positif kepada orang lain tanpa mendapatkan balasan apapun tetapi didasari rasa puas terhadap produk atau jasa yang ia konsumsi. Dimensi continue purchasing yang terdiri dari indikator kesediaan melakukan pembelian ulang dan tingkat kekebalan terhadap produk lain mendapatkan tanggapan paling rendah. Hal itu menunjukkan bahwa wisatawan belanja di Kota Bandung bersedia untuk menceritakan hal positif mengenai produk atau jasa kepada orang lain, merekomendasikan kepada orang lain akan tetapi tingkat kekebalan terhadap penawarn produk lain masih rendah. Banyaknya pilihan tempat wisata belanja di Kota Bandung membuat wisatawan belanja tidak hanya menetap pada satu pilihan tempat belanja saja. 3) wisatawan yang memiliki motif belanja hedonik lebih banyak dibandingkan dengan motif belanja utilitarian. 68,5\% wisatawan memiliki motif belanja hedonik dan sebesar $31,5 \%$ wisatawan bermotif utilitarian. Motif Hedonik merupakan suatu kebutuhan yang bersifat psikologis yang didasari rasa puas, gengsi, emosi, dan perasaan subjektif lainnya. Kebutuhan ini seringkali muncul untuk memenuhi tuntutan sosial dan estetika agar ia dapat mengikuti perkembangan jaman, individu yang bermotif hedonik secara emosional sulit dikendalikan apabila berada di suatu tempat belanja. 4) Berdasarkan hasil pengujian hipotesis membuktikan bahwa store attribute yang terdiri dari store atmosphere, convenience, merchandise, promotion, dan interpersonal communication secara simultan terdapat pengaruh yang signifikan terhadap loyalitas wisatawan belanja yang dikontrol oleh motivasi berbelanja.

\section{DAFTAR RUJUKAN}

Friedrich, W dan Sattler, K. (2005). Shopping Tourism in Germany. Impulses in The Development of Tourism and Retail, 
Haryanto, Bambang. (2014). Pengaruh Kualitas Produk dan Suasana Toko Terhadap Loyalitas,

Kotler, Philip dan Keller, Kevin Lanne. (2014). Marketing Management $14^{\text {th }}$ Edition Practice Hall. Pearson,

LeHew, Melody L.A., dan Wesley, Scarlett C. (2007). Tourist Shopper Satisfaction With Regional Shopping Mall Experience. International Journal of Culture, Tourism and Hospitality Research,

Lovelock, Christopher et.al. (2012). Essentials of ServiceMarketing. End Edition. Singapore: Prentice Hall,

Nguyen, T.T.M., Tho D.N., \& Nigel J.B. (2007). Hedonic Shopping Motivation and Shoppers Loyalty in transitional markets. Asia Pacific Journal Marketing and Logistics. Vol.19,

Novianti, Syifa. (2014) . Pengaruh Customer Based Brand Equity For Tourism Destination (CBBETD) Kota Bandung Sebagai Destinasi Wisata Belanja Terhadap Proses Keputusan Berkunjung Wisatawan Malaysia,

Sangadji, Etta Mamang dan Sopiah. (2013). Perilaku Konsumen. Yogyakarta: Andi,
Setiadi, Nugroho J. (2003). Perilaku Konsumen: Konsep dan Implikasi Untuk Strategi dan Penelitian Pemasaran. Jakarta: Prenada Media,

Subagio, Hartono dan Leha, Jeslyn Monica. (2011). Pengaruh Attribute Café Terhadap Motif Belanja Hedonik dan Utilitarian dan Loyalitas Pelanggan Starbucks Coffe di The Square Apartment Surabaya,

Tabanichnick dan Fidel. (2013). Using Multivariate Statistics, Sith Edition. Boston: Pearson Education, Inc,

Wang, Chiu Han dan Ha, Sejin. (2011). Store attributes Influencing Relatiomships Marketing : A Study of Department Stores. Journal of Fashion Marketing and Management. Vol. 15 No.3,

Yanuar, Irsan. (2013). Pengaruh Atribut SupermarketTerhadap Motif Belanja Hedonik dan Motif Belanja Utilitarian Serta Loyalitas Konsumen Carrefour di Surabaya,

Zeithaml, V., Bitner, M.J., dan Gremeler, D.D,. (2009). Services Marketing - Integrating Customer Focus Across the Firm 5th Edition. McGraw-Hill : Newyork. 